\section{Optimum Plant Population for Fresh-market Sweet Corn in the Northeastern United States}

\author{
Thomas F. M orris, ${ }^{1}$ \\ George $\mathrm{H}$ amilton, ${ }^{2}$ and \\ Sara $\mathrm{H}_{\text {arney }}^{3}$
}

Additional INDEX WORds. Zea mays, plant density, soil nitrate, dry matter yield

\begin{abstract}
Summary. There is little published data to support current recommended plant populations of 11,500 to 17,500 plants/ acre $(28,600$ to 34,600 plants/ ha) for fresh market sweet corn (Zea mays L.) in the northeastern U nited States. The plant population likely affects marketable yield and recovery of nitrate. R esidual soil nitrate is of concern because of the potential for nitrate contamination of water supplies. 0 ur objectives were to determine the effect of plant population on the yield of sweet corn grown for fresh market without irrigation and on the amount of nitrate in the surface $1 \mathrm{ft}(30 \mathrm{~cm})$ of soil at harvest. Seven main-season sweet corn varieties were planted in a total of eight experiments in 1995, 1996, and 1997. Seven experiments were in Connecticut and one was in $\mathrm{N}$ ew $\mathrm{H}$ ampshire. All but one of the varieties were standard (su) or sugary enhanced $(\boldsymbol{s})$ varieties. The experimental design was a randomized complete block with four replications,
\end{abstract}

Published as Storrs Agricultural Experiment Station journal paper 1869. We gratefully acknowledge the help of the dedicated staff at thePlant Science R esearch and $T$ eaching facility at the $U$ niversity of C onnecticut, and Richard Ashley for his suggestions. The cost of publishing this paper was defrayed in part by the payment of page charges. Under postal regulations, this paper therefore must be hereby marked advertise ment solely to indicate this fact.

${ }^{1} \mathrm{U}$ niversity of C onnecticut, D epartment of Plant Science, 1376 Storrs Road, Box U -67, Storrs, CT 06269 4067.

${ }^{2} \mathrm{U}$ niversity of $\mathrm{N}$ ew $\mathrm{H}$ ampshire $\mathrm{C}$ ooperative Extension System, 468 Route 13 South, M ilford, NH 030553445.

${ }^{3} U$ niversity of C onnecticut, D epartment of Plant Science, 1376 Storrs Road, Box U -67, Storrs, CT 06269 4067. and the treatments consisted of $12,000,16,000,20,000,24,000$, and 28,000 plants/ acre $(29,600,39,500$, $49,400,59,300$, and 69,200 plants/ ha). The yield of marketable ears was classified based on the length of the ears. The results suggest that the current recommendations for plant population in the N ortheast U S may be too low. Populations of 20,000 and 24,000 plants/ acre produced consistently greater yields of ears greater than 7.0 inches $(178 \mathrm{~mm})$ long. Soil nitrate-N concentrations at harvest were about $8 \mathrm{mg} \cdot \mathrm{kg}^{-1}$ lower with 16,000 plants/ acre or greater, compared with 12,000 plants/ acre, which suggests that populations of $16,000 /$ acre or greater should decrease the potential for nitrate contamination of water supplies in the fall, winter, and early spring.

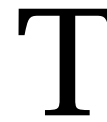

he recommended seeding rate for main-season sweet corn (Zea mays) planted for fresh market in N ew E ngland is 14,500 to 17,500 seeds/ acre $(35,800$ to 43,200 seeds/ ha) (Ferro et al., 1998). $\mathrm{H}$ arvest populations at these seeding rates would range from 11,600 to 14,000 plants/ acre $(28,700$ to 34,600 plants/ ha) if a $20 \%$ reduction in the population occurs due to nonviable seed and environmental factors. This recommendation has remained unchanged for at least 15 years (Ferro et al., 1983). Three states in the northeastern U nited States that grow large acreages of sweet corn for fresh market, Pennsylvania, New Jersey, and New York, recommend almost the same plant population for main-season sweet corn as the $\mathrm{N}$ ew England extension systems (Cornell C ooperative Extension, 1994; Garrison, 1999; Pennsylvania State Cooperative Extension, 1998). Research data to support these recommendations, to our knowledge, have not been published in scientific journals.

There is one recently published paper about optimal plant populations for sweet corn grown for fresh market in L ouisiana(H annaand Story, 1992). This experiment reported an optimal population of 34,600 plants/ acre $(86,100$ plants/ ha) for two super sweet varieties $\left(s_{2}\right)$ planted on 60 -inch (1.52m) beds with 18 inches $(46 \mathrm{~cm})$ between rows and drip irrigation. This optimal population is almost three times greater than the recommended population for fresh-market sweet corn in the northeastern $U$ nited States, but the data likely are not applicable because of climate differences and because the row spacing is not commonly used there.

The sweet corn varieties grown in thenortheastern U nited Statesaresimilar to the recommended varieties for fresh market in O regon and $M$ innesota. The plant populations at harvest recommended by the Extension Services in these states are 20,000 to 25,000 plants/ acre $(49,400$ to 61,750 plants/ ha) (O regon StateU niv. , 1999; U niv. of M innesota, 1999), which is about $60 \%$ greater than the recommended harvest population in the N ortheast. Research data to support the $M$ innesota and $O$ regon recommendations for fresh market sweet corn, to our knowledge, have not been published in scientific journals.

There are published studies from $M$ innesota and O regon for optimal plant populations for sweet corn used for processing. Mack (1972) in Oregon showed that aharvest population of 39,500 to 54,300 plants/ acre $(97,600$ to 134,200 plants/ ha) (plant populations multiplied by correction factor 6.1, M ack, 1973) produced more yield compared with a population of 14,800 to 19,800 plants/ acre $(36,600$ to 48,800 plants/ ha) for the 'J ubilee' and 'Golden Cross Bantam' varieties, in 36-inch (91-cm) wide rows and irrigated conditions. In another study in Oregon (Moss and Mack, 1979), the optimal plant population was 25,700 to 44,500 plants/ acre $(63,400$ to 109,800 plants/ ha) for irrigated conditions and the J ubilee variety. In M innesota, a 1-year study using three plant populations, $17,000,22,000$, and 27,000 plants/ acre, $(42,000,54,340$, and 66,700 plants/ ha) with 'J ubilee' and dryland conditions showed that 22,000 plants/ acreprovided thegreatest number of usable ears ( $R$ osen and Fritz, 1987). Thesethreestudiesevaluated only two processing varieties, and it is unknown what effect plant population would have on varieties used for fresh market.

Sweet corn varietiesfor fresh market have changed considerably in the past 20 years. The varieties 'Silver Q ueen' and 'Sweet Sue' probably are the only two varieties planted in the past that are commonly planted today. The recommendationsfor plant population in the northeastern U nited States might becorrect for these old varieties 
T able 1. Selected information about the sweet corn varieties, locations, and years of the eight plant population experiments.

\begin{tabular}{|c|c|c|c|c|c|}
\hline L ocation ${ }^{2}$ & Year & Variety & $\begin{array}{c}\text { H ybrid } \\
\text { type }\end{array}$ & $\begin{array}{c}\text { Kernel } \\
\text { color }\end{array}$ & $\begin{array}{l}\text { R elative } \\
\text { maturity } \\
\text { (d) }\end{array}$ \\
\hline CT & 1995 & Sweet Sue & su & Bicolor & 88 \\
\hline $\mathrm{NH}$ & 1996 & Twilight & se & Bicolor & 78 \\
\hline $\mathrm{CT}$ & 1996 & Sweet I ce & SB & White & 74 \\
\hline $\mathrm{CT}$ & 1996 & Silver Q ueen & su & White & 92 \\
\hline CT & 1997 & Twilight & se & Bicolor & 78 \\
\hline $\mathrm{CT}$ & 1997 & Bodacious & se & Yellow & 72 \\
\hline
\end{tabular}

${ }^{{ }^{2} \mathrm{CT}}=\mathrm{U}$ niversity of C onnecticut Plant Science Research and Teaching Facility; $\mathrm{NH}=$ a grower's field in $\mathrm{H}$ ollis, $\mathrm{N}$.H

${ }^{\text {y }}$ S = standard; se = sugary enhanced; SB = Sweet Breed hybrid from H arris Seeds, Rochester, N .Y.

if weassume the recommendationsare based on valid but unpublished data. Information about the effect of plant population on the yield of the new generation of sweet corn varieties grown for fresh market is needed to maximizetheprofitability of sweet corn production. H arvesting the optimal plant population is a critical factor affecting the profitability of sweet corn becausethenumber of marketableears directly affects the grower's gross return.

$\mathrm{H}$ arvesting the optimal plant population may reduce the potential for loss of nitrate from sweet corn fields because of increased removal of nitrate. In the studies with processing varieties of sweet corn in Oregon (M ack, 1972; M oss and M ack, 1979), the total plant dry matter yield increased with increasing plant population. Because theaccumulation of more dry matter likely would result in the removal of more nitrate from the field and the sequestration of much of the nitrate as organically-bound nitrogen, increasing the plant population should reduce the amount of nitrate available for leaching during the fall, winter and early spring. Research with field corn in Connecticut (Guillard et al., 1995) indicates that nitrate is most susceptible to leaching during this time period.

The objectives of this study were to determine the effect of plant population on 1) the yield of sweet corn grown for fresh market without irrigation and 2) theamount of nitratein the surface $1 \mathrm{ft}(30 \mathrm{~cm})$ of soil at harvest.

\section{Methods and materials}

Seven different main-season sweet corn hybrids were planted. Five of the seven varieties were newer releases and two, 'Silver Q ueen' and 'Sweet Sue', are commonly planted older releases. We planted a wide diversity of varieties becausewewanted to test the response of many varieties to changes in plant population. All the varieties, except 'Sweet I ce', were standard (su) or sugary enhanced ( $œ)$ varieties. Selected information about the varieties, and the years and locations of the experimentsis shown in Table 1. The experimental design wasa randomized complete block, and the treatments were five plant populations ranging from 12,000 to 28,000 plants/ acre $(29,600$, to 69,200 plants/ ha) in increments of 4,000 plants/ acre (9,900 plants/ ha). Each treatment was replicated four times. Thetreatmentswereestablished in Connecticut by seeding about 40,000 seeds/ acre $(99,000$ seeds/ ha) in 30-inch $(76-\mathrm{cm})$ rows, and theplants werehand-thinned to thedesired populations when corn plants were 6 to 10 inches ( 15 to $25 \mathrm{~cm}$ ) tall. Plots were 4 rows wide and $20 \mathrm{ft}(6.1 \mathrm{~m})$ long. In $\mathrm{N}$ ew $\mathrm{H}$ ampshire, the correct populations were seeded in 36 -inch $(91-\mathrm{cm})$ wide rows by a hand planter in plots that were 8 rows wide and $40 \mathrm{ft}(12.2$ $\mathrm{m})$ long. All experiments were planted in the first half of J une in each year. All mature ears that met the U SD A standard for Fancy grade (U SD A, 1954) wereharvested from $10-\mathrm{ft}(3.0-\mathrm{m})$ sections of the center two rows of each plot. The ears were weighed, husked, and the shank was cut flush with the ear to ensure accurate measurement of ear length. Each ear was measured for ear length, and the yields are reported as the number of ears per acre for various lengths. In 1995, the only year when there were unfilled ear tips, un- filled tips greater than 0.5 inch (13 $\mathrm{mm}$ ) were measured. The stalks in the harvest area were cut and weighed. Eight stalks and eight ears were randomly chosen for dry matter determination, and the yields are reported as total plant dry matter in tons/ acre. Lodging was not observed in the experiments. Corn in all the experiments was not irrigated, except in the $\mathrm{N}$ ew $\mathrm{H}$ ampshire experiment in August.

The soil in Connecticut was a Woodbridge fine sandy loam (coarseloamy, mixed, mesic, Aquic D ystrochrept). This soil is widely used for agricultural production in $\mathrm{New}$ England. The rooting depth and sampling depth in theW oodbridgesoil are restricted to about $2 \mathrm{ft}(61 \mathrm{~cm})$ because of the presence of compact basal till that begins at a depth of 20 to 24 inches (51 to $60 \mathrm{~cm}$ ). The soil in $\mathrm{N} \mathrm{ew}$ $\mathrm{H}$ ampshire was a Canton fine sandy loam (coarse-loamy over sandy or sandy-skeletal, mixed, mesic, Typic Dystrochrept). Phosphorus and potassium were broadcast before planting according to soil test results. The soil $\mathrm{pH}$ in the experimentsvaried from 6.1 to 6.8. No manure had been applied to the fields for at least 10 years. The crops grown in the year before establishment of the experiments were Sudax (variety 'Ciba FP-5'), a sorghum-sudangrass hybrid [Sorghum bi color (L.) x Sorghum sudanense (Piper) Stapf] or sweet corn. N itrogen asurea was broadcast and immediately incorporated before planting at 175 $\mathrm{lb} /$ acre $\left(196 \mathrm{~kg} \cdot \mathrm{ha}^{-1}\right)$ for all the experiments in Connecticut. The $\mathrm{New}$ $\mathrm{H}$ ampshire experiment received 128 $\mathrm{lb} /$ acre (143 $\left.\mathrm{kg} \cdot \mathrm{ha}^{-1}\right)$ of $\mathrm{N}$ as ammonium nitrate before planting. Weeds were controlled in Connecticut using 
Table 2. R ainfall data for each year from $M$ ay through August.

\begin{tabular}{lcccccc}
\hline & \multicolumn{7}{c}{ Rainfall (inches) $^{\mathbf{z}}$} \\
\cline { 2 - 7 } Year & Deviation $^{\mathbf{y}}$ & May & J une & July & August & Total \\
\hline 1995 & -4.0 & 3.3 & 1.8 & 4.0 & 2.2 & 11.4 \\
1996 & 0.1 & 3.1 & 2.8 & 7.3 & 2.2 & 15.5 \\
$1996 \mathrm{NH}^{\times}$ & -2.0 & 4.8 & 3.0 & 5.2 & 0.1 & 13.1 \\
1997 & -3.5 & 3.0 & 1.6 & 2.5 & 4.8 & 11.9 \\
\hline
\end{tabular}

z1.0 inch $=25.4 \mathrm{~mm}$.

YT otal deviation from 100-year mean rainfall for Storrs, Conn., and 30-year mean rainfall for $\mathrm{N}$ ew $\mathrm{H}$ ampshire.

${ }^{x} \mathrm{D}$ ata for experiment in H ollis, N.H ., in 1996.

preemergence broadcast applications (a.i.) of atrazine [2-chloro-4(ethylamino)-6-(isopropylamino)-striazine] at $1.0 \mathrm{lb} /$ acre $\left(1.12 \mathrm{~kg} \cdot \mathrm{ha}^{-1}\right)$ and metolachlor [2-chloro- $\mathrm{N}-(2-$ ethyl-6-methylphenyl) - N - (2methoxy-1-methylethyl) acetamide] at $2 \mathrm{lb} /$ acre $\left(2.24 \mathrm{~kg} \cdot \mathrm{ha}^{-1}\right)$; in $\mathrm{New}$ $\mathrm{H}$ ampshire preemergence broadcast applications of atrazine at $1.0 \mathrm{lb} /$ acre $\left(1.12 \mathrm{~kg} \cdot \mathrm{ha}^{-1}\right)$ and alachlor [2-chloro2', 6'-diethyl- $\mathrm{N}$-(methoxmethyl)-acetanilide] at $1.5 \mathrm{lb} / \mathrm{acre}\left(1.68 \mathrm{~kg} \cdot \mathrm{ha}^{-1}\right)$ were used.

Soil samples were collected from theexperimentsin Connecticut in 1996 and 1997 from the harvest area in each plot immediately after harvest. Each sample was composed of six cores $7 / 8$ inch $(2.2 \mathrm{~cm})$ in diameter collected from the surface $1 \mathrm{ft}(30 \mathrm{~cm})$ of soil. The samples were spread to air-dry in a thin layer within $1 \mathrm{~h}$ of collection. The dried samples were sieved to pass a 0.08 -inch $(2-\mathrm{mm})$ screen, extracted with $0.01 \mathrm{M} \mathrm{CaCl}_{2}$, and the nitrate- $\mathrm{N}$ concentrations were determined by using a Scientific Instruments (WEST CO, D anbury, Conn.) segmented-flow analyzer.

Statistical analysisinvolved theuse of orthogonal contrasts to test for the linear and quadratic effects of plant population on ear numbers, dry matter yield, and soil nitrate- $\mathrm{N}$ concentrations in the fall. The plant populations where there were no further significant increases in ear numbers and dry matter yield or significant decreases in soil nitrate- $\mathrm{N}$ concentrations were delineated by using orthogonal singledegree-of-freedom contrasts. Thecontrastsweretheyieldsor the soil nitrate$\mathrm{N}$ concentrationsfrom theplant populations at 12,000 plants/ acre $\left(\mathrm{P}_{12,000}\right)$ vs the average of the yields at the higher plant populations $\left(\mathrm{P}_{16,000}, \mathrm{P}_{20,000}\right.$, $\left.P_{24,000,}, P_{28,000}\right)$, etc. All statistical analyseswere performed in the GL M procedure of SAS (SAS Institute, 1993), and an alpha level of 0.05 was used to declare significance for all analyses.

\section{Results and discussion}

Rainfall during the growing season was below-average for all years except for 1996 in Connecticut, when rainfall was average (T able 2 ). Visual inspection of the corn plants in the 1995 and 1997 experimentsindicated drought stress during the vegetative stage of growth, but no visibledrought stress during the reproductive stage of growth.

Drought stress and higher than recommended plant populations are thought to greatly increase the chances of producing many small, unmarketable ears and many ears with unfilled tips. In 1995, when the variety 'Sweet Sue' was planted, higher than recommended plant populationsand drought stress during vegetative growth did not cause a significant decrease (linear or quadratic) in the number of ears with filled tips (Table 3). There was a significant linear increase in the number of ears with unfilled tips and in the average length of the unfilled tips as the plant population increased (Table $3)$. These results suggest that high plant populations and early-season drought stress will not always result in substantial reductions in the yield of the ears. Further evidence that higher than recommended plant populations and drought stress do not always reduce yield is shown by the yields of varieties 'Silver King', 'T wilight' and 'Bodacious' in 1997 (Fig. 1), when there was drought stress. Drought stressincreased thecoefficients of variation for the yield of these varieties compared with the coefficients for the yields of the varieties planted in 1996 (Table 4), which was a year with average rainfall. It is unknown whether a more severe drought, especially dur-

T able 3. N umber of ears and the length of ears for 'Sweet Sue' variety in 1995 at various plant populations in Storrs, Connecticut.

\begin{tabular}{lccccc}
\hline Plants/acre & Plants/ha & $\begin{array}{c}\text { Filled } \\
\text { ears }^{\mathbf{y}}\end{array}$ & $\begin{array}{c}\text { U nfilled } \\
\text { ears } \\
\text { (ears/acre) }\end{array}$ & $\begin{array}{c}\text { T otal } \\
\text { ears }\end{array}$ & $\begin{array}{c}\text { Avg length of } \\
\text { unfilled ear tip } \\
\text { (inches) }^{\mathbf{x}}\end{array}$ \\
\hline 12,000 & 29,600 & 7,840 & 3,700 & 11,540 & 0.55 \\
16,000 & 39,500 & 8,280 & 7,400 & 15,680 & 0.87 \\
20,000 & 49,400 & 7,620 & 8,900 & 16,540 & 0.87 \\
24,000 & 59,300 & 7,400 & 13,500 & 20,910 & 0.98 \\
28,000 & 69,200 & 5,660 & 12,200 & 17,860 & 1.14 \\
Significance & & NS & L & $L, Q$ & $L$ \\
\hline
\end{tabular}

zEars with unfilled tips greater than 0.5 -inches ( $13 \mathrm{~mm}$ ) long.

yEars filled to within 0.5 inches of the end of the ear, 1 ear/ acre $=2.47$ ears/ ha.

${ }^{x} 1.0$ inch $=25.4 \mathrm{~mm}$.

Ns, ${ }^{*} \mathrm{~N}$ onsignificant or significant response to plant population at $\mathrm{P} \leq 0.05 ; \mathrm{L}=$ linear and $\mathrm{Q}=$ quadratic. 
T able 4. Probability $(P)$ of a greater $F$ value for the interaction term variety by plant population for the combined AN OVA for the variable ear length and the coefficient of variation values (CV) for the AN OVAs.

\begin{tabular}{|c|c|c|c|c|c|c|}
\hline \multirow{2}{*}{$\begin{array}{l}\text { Ear length } \\
\text { [inches }(\mathrm{mm}) \text { ] }\end{array}$} & \multicolumn{2}{|c|}{1996} & \multicolumn{2}{|c|}{1997} & \multicolumn{2}{|c|}{ 1995, 1996 and 1997} \\
\hline & $P>F$ & CV (\%) & $P>F$ & CV (\%) & $P>F$ & CV (\%) \\
\hline $6.0(15.2)$ & 0.33 & 9.8 & 0.06 & 11.7 & 0.001 & 10.7 \\
\hline $6.5(16.5)$ & 0.54 & 8.4 & 0.09 & 12.4 & 0.01 & 11.3 \\
\hline $7.0(17.8)$ & 0.03 & 10.9 & 0.40 & 17.9 & 0.03 & 15.1 \\
\hline $7.5(19.1)$ & 0.26 & 22.2 & 0.60 & 41.2 & 0.40 & 32.8 \\
\hline
\end{tabular}

6.0-inch data for all varieties; 6.5- and 7.5-inch data for all varieties except 'Sweet Sue', 'T wilight' in 1997, and 'Sweet I ce'; 7.0-inch data for all varieties except 'Sweet Sue' and 'T wilight' in 1997.

ing the reproductive stage of growth, would cause large reductions in ear numbers and size at higher than recommended plant populations.

The varieties planted in these experimentshad different yield responses to increases in plant population (Fig. 1 ). When the varieties are combined across all three years for an analysis of variancetherewasasignificant interaction between variety and plant population for all ear lengths, except for the 7.5-inch (190-mm) length (Table 4). In 1996, theinteraction of variety with population for the ear yield wassignifi- cant for the 7.0-inch (178-mm) ear length. In 1997, the interactions for the four ear lengths were not significant, but two of the ear lengths, the 6.0-inch $(152-\mathrm{mm})$ and the 6.5 -inch (165-mm) lengths, had $P$ values close to the 0.05 significance level ( $T$ able $4)$. These differences in the yield responseslikely were due to the different genetic backgrounds of the varieties, as shown by their different colors and maturities. The nonuniform yield response across the varieties suggests that growers will need to plant different populations for different varieties if they want to maximize the yield of sweet corn. Because of the nonuniform yield response to population, the results for ear yield for each variety were examined separately.

The yield of ears greater than 6 inches long for 'Twilight' in 1996 significantly increased with increasing plant population up to 28,000 plants/ acre (Fig. 1; T able 5). These results and the resultsfor 'Sweet Sue' in 1995 (Table 3) suggest that the recommended plant population at harvest in theN ortheast of about 12,000 plants/ acre for main-season sweet corn is too
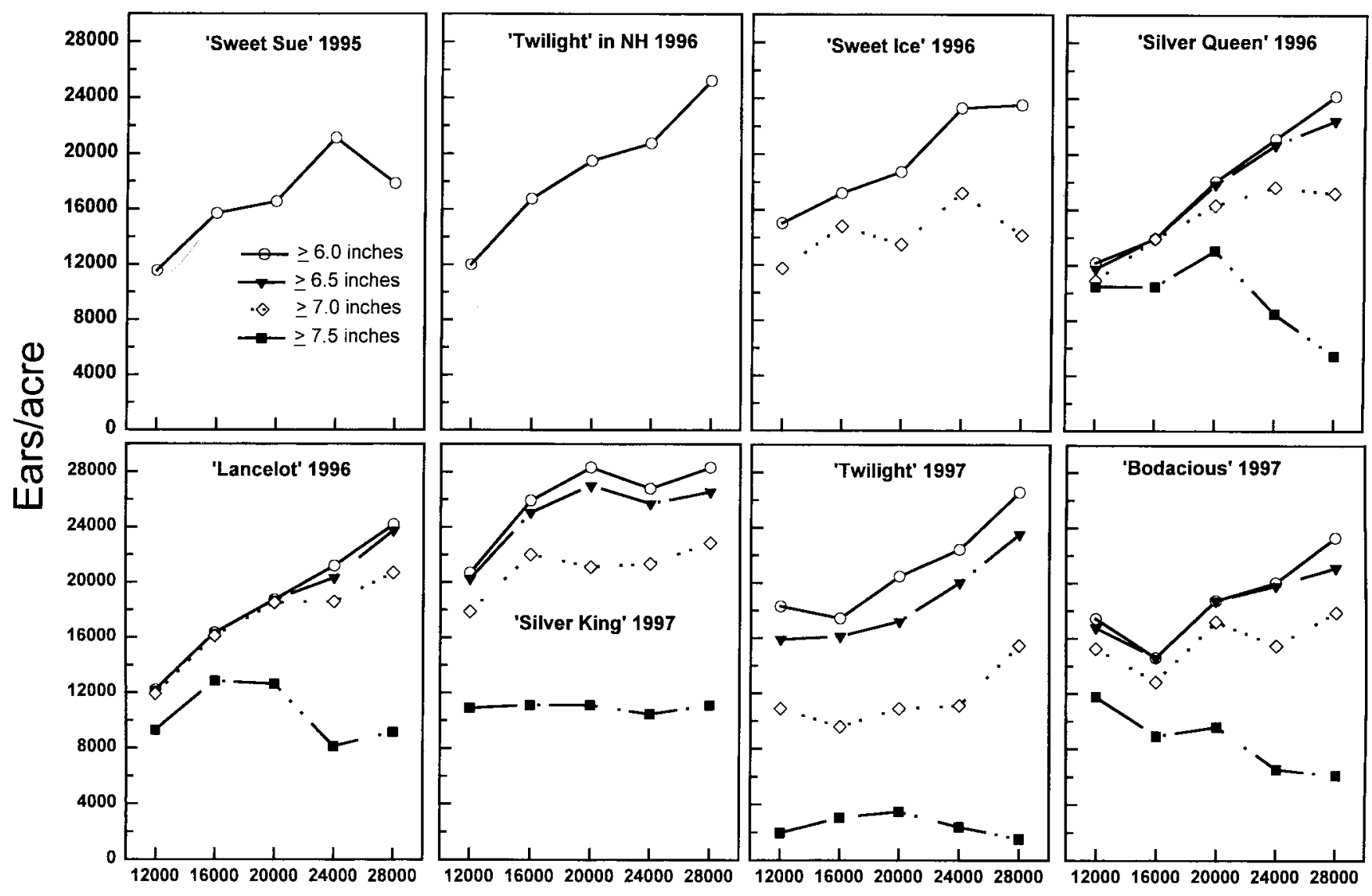

\section{Plants/acre}

Fig. 1. R elationship between ear yield of seven sweet corn varieties and five plant populations at four ear lengths ( 1 ear or plant/acre $=2.47$ ears or plants $/$ ha; 1.0 inch $=25.4 \mathrm{~mm}$ ). 
Table 5. The plant population for each variety and ear length at which there was no further significant yield increase in ear number based on orthogonal single-degree-of-freedom contrasts. ${ }^{2} L$ etters indicate a linear response (L) or a quadratic response (Q) to plant population.

\begin{tabular}{lcccccccc}
\hline & \multicolumn{6}{c}{ Plant population at which the ear yield stopped increasing for each variety } \\
(plants/acre)
\end{tabular}

zPlant population at which a significant increase in ear yield stopped based on orthogonal single-degree-of-freedom contrasts $(\mathrm{P} \leq 0.05)$ where the contrasts are the yields from the populations at 12,000 plants/ acre $\left(\mathrm{P}_{12,000}\right)$ vs the average of the yields at the higher plant populations $\left(\mathrm{P}_{16,000}, \mathrm{P}_{20,000}, \mathrm{P}_{24,000}, \mathrm{P}_{28,000}\right)$; and $\mathrm{P}_{16,000} \mathrm{vs}\left(\mathrm{P}_{20,000,}, \mathrm{P}_{24,000,}, \mathrm{P}_{28,000}\right)$, etc., except for 'Silver Q ueen' and 'L ancelot' at 7.5 inches where the contrasts were calculated using only the first three plant populations.

y1 plant/ acre $=2.47$ plants/ ha.

×ND = not determined.

${ }^{\mathrm{N} N} \mathrm{~N}$ onsignificant for linear $(\mathrm{L})$ and quadratic $(\mathrm{Q})$ terms at $\mathrm{P} \leq 0.05$.

Table 6. T otal plant dry matter yields of sweet corn varieties at different plant populations in Storrs, C onn., in 1996 and 1997.

\begin{tabular}{|c|c|c|c|c|c|c|c|}
\hline \multirow[b]{2}{*}{ Plants/acre } & \multicolumn{7}{|c|}{ Variety (tons dry matter/acre) ${ }^{z}$} \\
\hline & $\begin{array}{c}\text { Sweet } \\
\text { I ce }\end{array}$ & $\begin{array}{l}\text { Silver } \\
\text { Q ueen }\end{array}$ & L ancelot & $\begin{array}{l}\text { Silver } \\
\text { King }\end{array}$ & Twilight & Bodacious & Mean \\
\hline 12,000 & 1.75 & 3.64 & 2.80 & 4.33 & 3.12 & 2.48 & 3.02 \\
\hline 16,000 & 2.18 & 4.17 & 3.35 & 4.46 & 3.07 & 2.72 & 3.33 \\
\hline 20,000 & 2.29 & 4.30 & 3.60 & $5.03^{x}$ & $3.67^{x}$ & $3.51^{x}$ & 3.74 \\
\hline 24,000 & $2.62^{x}$ & $4.69^{x}$ & 3.89 & 5.34 & 3.74 & 3.41 & 3.95 \\
\hline 28,000 & 2.79 & 4.90 & $4.41^{x}$ & 5.44 & 4.14 & 3.85 & $4.26^{x}$ \\
\hline \multirow[t]{2}{*}{ CV (\%) } & 7.0 & 6.4 & 7.2 & 6.6 & 10.1 & 7.8 & 8.7 \\
\hline & $L^{w}$ & $\mathrm{~L}$ & $\mathrm{~L}$ & L & L & L & L \\
\hline
\end{tabular}

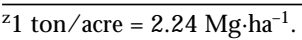

y1 plant/ acre $=2.47$ plants/ ha.

xPlant population at which a significant increase in ear yield stopped based on orthogonal single-degree-of-freedom contrasts $(P \leq 0.05)$ where the contrasts are the yields from the populations at 12,000 plants/ acre $\left(P_{12,000}\right)$ vs the average of the yields at the higher plant populations $\left(P_{16,000}, P_{20,000}, P_{24,000}, P_{28,000}\right) ;$ and $P_{16,000}$ vs $\left(P_{20,000,}, P_{24,000,}, P_{28,000}\right)$ etc.

${ }^{w} \mathrm{~L}=$ linear increase in dry matter was significant at $\mathrm{P} \leq 0.05$; quadratic term was not significant at all locations.

low. Because most buyers and consumers of fresh market sweet corn prefer ears that are at least 7.0 inches long, we grouped the ear yields of subsequent varieties into more earlength categories to better estimate the effect of plant population on the marketability of sweet corn.

The variety 'Sweet I ce' had a significant increase in ear yield up to 24,000 plants/ acre for ears equal to or greater than 6.0 inches long (Fig 1; Table5). When ears equal to or greater than 7.0 inches long were measured, 16,000 plants/ acre was the population where significant increases in ear yield stopped. This variety would produce 3,050 (7,530 ears/ ha) more 7.0inch ears from a plant population of 16,000 plants/ acre compared with a population of 12,000 plants/ acre.

The variety 'Silver Q ueen' is an old variety that often is planted in the northeastern U nited States because of its ability to produce large ears. G row- ers usually prefer a harvest plant population of about 12,000 plants/ acrefor this variety because it has a reputation for producing low yields of marketable ears at plant populations greater than 12,000 plants/ acre. O ur results suggest that 'Silver Q ueen' can produce a large number of 7.0 -inch ears at a population of 20,000 plants/ acre(Fig. 1 ; Table 5). If an ear length of 6.5

inches is marketable, 28,000 plants/ acre, or more than double the recommended plant population in thenortheastern U nited States, would produce the most ears. $M$ any growers will hesitate to use a population this high because 'Silver Q ueen' produces a tall plant that issusceptibleto lodging, but in this experiment 'Silver Q ueen' did not lodge. $O$ ur results for this variety

Table 7. Average soil nitrate $\mathrm{N}$ concentrations in the surface $1 \mathrm{ft}(30.5 \mathrm{~cm})$ of soil at harvest for different plant populations when $\mathrm{N}$ was applied at $175 \mathrm{lb} / \mathrm{acre}$ $\left(196 \mathrm{~kg} \cdot \mathrm{ha}^{-1}\right)$ before planting in Connecticut in 1996 and 1997.

\begin{tabular}{lcc}
\hline Plants/acre & Plants/ha & Soil nitrate $\mathbf{N}\left(\mathbf{m g} \cdot \mathbf{k g}^{-\mathbf{1}} \mathbf{)}\right.$ \\
\hline 12,000 & 29,600 & 39.1 \\
16,000 & 39,500 & $29.4^{2}$ \\
20,000 & 49,400 & 33.3 \\
24,000 & 59,300 & 30.0 \\
28,000 & 69,200 & 31.4
\end{tabular}

zPlant population at which a significant decreasein soil nitrate- $\mathrm{N}$ concentrationsstopped based on orthogonal singledegree-of-freedom contrasts $(P \leq 0.05)$ where the contrasts are the average soil nitrate-N concentrations from the populations at 12,000 plants/ acre $\left(\mathrm{P}_{12,000}\right)$ vs the average of the concentrations at the higher plant populations $\left(\mathrm{P}_{16,000}, \mathrm{P}_{20,000}, \mathrm{P}_{24,000}, \mathrm{P}_{28,000}\right)$; and $\mathrm{P}_{16,000}$ vs $\left(\mathrm{P}_{20,000}, \mathrm{P}_{24,000,}, \mathrm{P}_{28,000}\right)$, etc.; 1 plant/ acre $=2.47$ plants/ ha. 
suggest that growers should experiment with higher populations than they traditionally use.

A nother variety that is grown for its ability to produce large ears is ' $L$ ancelot'. The results for this largeeared variety are similar to the results for 'Silver Q ueen'. The plant population at which there was no further significant yield increase was much higher than the recommended plant population of about 12,000 plants/ acre for all ear lengths (Fig. 1; Table $5)$. A harvest population of 20,000 plants/ acre for ' $L$ ancelot' would produce 6,600 (16,300 ears/ ha) more 7.0-inch earscompared with a population of 12,000 plants/ acre.

A harvest population greater than 16,000 plants/ acre did not significantly change the yield of the 'Silver King' variety for all ear-length categories except for the 7.5-inch ear length (Fig. 1; Table 5). The varieties 'T wilight' and 'Bodacious' in 1997 showed no significant increases in yield for the longer ear-length categories ( $T$ able5). The 'Bodacious' variety had a significant decrease in yield at the 7.5-inch ear length. These results suggest that the benefits of higher than recommended plant populations would not be as great in years of low rainfall, but large reductions in yields also are not likely. $\mathrm{H}$ igher populations would produce more unmarketable ears in years of low rainfall, which would increase the cost of production due to greater labor costs for culling and sorting.

The total plant dry matter yield of each variety significantly increased with increasing plant population (Table 6). When the data are combined for the six varieties, the interaction of variety by plant population for the dry matter yield was not significant ( $P=0.75)$. This lack of interaction for variety by population for the dry matter yield, and the significant interactions for variety by plant populations for ear yield (Table 5) indicates that the ear yield is more sensitive than the total dry matter yield to external factors, such as rainfall, that control yield.

The nitrate- $\mathrm{N}$ concentration in the surface $1 \mathrm{ft}$ of soil in the fall has been shown to be a good predictor of the potential for leaching of nitrate from cornfields in Pennsylvania during the winter (Roth and Fox, 1990) The average nitrate- $\mathrm{N}$ concentrations in the surface $1 \mathrm{ft}$ of soil at harvest in Connecticut in 1996 and 1997 did not dramatically decrease with increasing plant population (Table 7). The lowest population had a significantly greater nitrate- $\mathrm{N}$ concentration compared with the average of the higher populations, but the nitrate-N concentrations for plant populations of $16,000 /$ acre or greater were not significantly different from one another. Thesoil nitrate- $\mathrm{N}$ concentrationswere quite variable ( $c v=40.3 \%$ ), which is not unusual for this nutrient (M eisinger, 1984). These results suggest that populations of 16,000 plants/ acre or greater would reduce the potential for nitrate pollution of water bodies because lower concentrations of nitrate in the soil at harvest have been shown to result in less nitrate leaching from field corn during the fall and winter (Guillard et al., 1995).

\section{Conclusions}

O ptimum plant populations for the varieties used in our experiments were almost always greater than the recommended plant populationsin the northeastern U nited States. The optimum plant population changed with the variety and with the length of the ear. A range of plant populations at harvest of 20,000 to 24,000 plants/ acre seems a reaso nable recommendation based on the response of the varieties used in these experiments. This recommendation assumes adequate rainfall or irrigation at the time of ear development. We prefer to recommend a plant population at harvest instead of a rate of seeding because we believe growers have the best information about the expected survival rate for seeds planted in their fields. Because other varieties may respond differently to plant populations, growers should experiment with a few different plant populations before planting a large portion of their acreage to higher populations. Plant populations of 16,000 plants/ acre or greater should decrease the potential for nitrate contamination of water supplies in the fall, winter, and early spring when sweet corn is fertilized with $\mathrm{N}$ at $175 \mathrm{lb} /$ acre.

\section{Literature cited}

Cornell Cooperative Extension. 1994. Cornell recommends: Vegetable production handbook. Publ. N 0.142V PH . Cornell Coop. Ext., I thaca, N.Y.

Ferro, D.N., G.W. M oorman, and R.J. Precheur.
1983. N ew England vegetable production recommendations. U niv. M ass. Coop. Ext. Serv. Publ. 1/ 83-5M-C-137.

Ferro, D.N ., A.R. Bonanno, W.H . Erhardt, and R.L. Wick. 1998. N ew England vegetable management guide. U niv. M ass., O ffice Commun., College Food Natural Resources Publ. AG1282:10/ 97

Garrison, S.A. 1999. Commercial vegetableproduction recommendations. RutgersU niv. Coop. Ext. (N ew Brunswick, N .J.) Publ. E0010.

Guillard, K., G.F. Griffin, D.W. Allinson, W.R. Yamartino, M. M oosa R afey, and S.W. Pietrzyk. 1995. N itrogen utilization of selected cropping systems in the U.S. northeast: II. Soil profile nitrate distribution and accumulation. Agron. J . 87:199-207.

H anna, H.Y. and R.N. Story. 1992. Yield of super sweet corn as affected by $\mathrm{N}$ application timing, plant density, tiller removal, and insecticides. Proc. Fla. State H ort. Soc. 105:343344.

M ack, H .J . 1972. Effects of population density, plant arrangement, and fertilizers on yield of sweet corn. J. Amer. Soc. H ort. Sci. 97:757760.

M ack, H .J . 1973. Correction factor for yields. J. Amer. Soc. H ort. Sci. 98:128.

M eisinger, J.J . 1984. Evaluating plant-available nitrogen in soil-crop systems, p. 391-416. In: R. H auck (ed.). Nitrogen in crop production. Amer. Soc. Agron., M adison, Wis.

M oss, J.D. and H.J. Mack. 1979. Effects of plant density and nitrogen fertilizer on sweet corn. H ortScience 14:176-177.

O regon State U niversity. 1999. Commercial vegetable production guide, sweet corn and popcorn. O regon State U niv. Ext. Serv. Web Page http:/ / www.osu.orst.edu/ Dept/ NWREC/ corn-fr.html.

PennsylvaniaStateC ooperativeExtension. 1998. Commercial vegetable production recommendations. Pa. State U niv. Coop. Ext., U niversity Park.

Rosen, C. and V. Fritz. 1987. Planting date, nitrogen fertilizer, and plant population interactions in processing sweet corn-1987. U niv. of M innesota, S. Expt. Sta. (Waseca) Res. Rpt.

Roth, G.W. and R.H. Fox. 1990. Soil nitrate accumulationsfollowing nitrogen-fertilized corn in Pennsylvania. J. Environ. Q ual. 19:243-248.

SAS Institute. 1993. SAS/ STAT user's guide. 4th ed. vers. 6. SAS Inst., Cary, N.C.

U niversity of M innesotaExtension Service. 1999. $\checkmark$ egetable crop management, sweet corn. U niv. M innesota Ext. Serv. Web Page, 29 D ec. http:/ / www.extension.umn.edu/ distribution/ cropsystems/ DC 1000.html.

U SD A. 1954. U nited Statesstandardsfor grades of green corn. Fed. Reg. 19 FR 2221, 17 Apr. 